\title{
METODE PEMAHAMAN HADIS ULAMA KONTEMPORER NON-AHLI HADIS (STUDI KOMPARATIF ANTARA PERSEPSI MUHAMMAD AL-GHAZALI DAN PENDAPAT YUSUF AL-QARDHAWI)
}

\author{
Muhammad Idris \\ UIN Imam Bonjol Padang, mbdidris987@gmail.com \\ Taufiqurrahman Nur Siagian \\ LAIN Padang Sidempuan, taufiq_nur@gmail.com
}

Diterima: 6 Juni 2018

Direvisi : 13 Oktober 2018

Diterbitkan: 30 Desember 2018

\begin{abstract}
Hadith is the second main source of Islamic teaching after the Qur'an. To understand it in depth, a comprehensive study with certain methods and approaches is needed to be able to capture the intent of a hadith. In accordance with the times, contemporary scholars try to understand a badith with their respective methods of understanding. Among the contemporary scholars were Muhammad al-Ghazali and Yusuf al-Qardhawi. They offer several methods for understanding the Prophet's hadith. According to al-Ghazali, the method of understanding the Prophet's hadith must be measured from the four criteria of the hadith validity, namely: the hadith must be in accordance with the Koran, the hadith must be in accordance with other saheeh traditions, the badith must be in accordance with bistorical facts, the hadith must be in accordance with scientific truth. While Yusuf al-Qardhawi is broader than the four things put forward by Muhammad al-Ghazali.
\end{abstract}

Keywords: Hadis, Muhammad al-Ghazali, Yusuf al-Qardhawi

\begin{abstract}
Abstrak
Hadis merupakan sumber pokok ajaran Islam yang kedua setelah Alquran. Untuk. memahaminya secara mendalam dibutubkan kajian secara komprehensif dengan metode dan pendekatan tertentu agar mampu menangkap maksud sebuah hadis. Sesuai dengan perkembangan zaman, para ulama kontemporer mencoba memahami sebuah hadis dengan metode pemahaman mereka masing-masing. Di antara ulama kontemporer itu adalah Muhammad al-Ghazali dan Yusuf al-Qardhawi. Mereka menawarkan beberapa metode untuk memahami hadis Nabi. Menurut al-Ghazali, metode pemahaman hadis Nabi harus diukur dari empat kriteria keshahihan matan hadis, yaitu: matan hadis harus sesuai dengan Alquran, matan hadis harus sesuai hadis shabih lainnya, matan hadis harus sesuai dengan fakta sejarah, matan hadis harus sesuai dengan kebenaran ilmiah. Sementara Yusuf al-Qardhawi lebih luas dari empat hal yang dikemukakan Muhammad al-Ghazali.
\end{abstract}

Kata Kunci: Hadis, Muhammad al-Ghazali, Yusuf al-Qardhawi

\section{PENDAHULUAN}

Sejak pertengahan abad ke-19, definisi otoritas Rasulullah menjadi masalah penting bagi para pemikir Muslim. Karena abad ini merupakan periode ketika hegemoni barat yang berkaitan dengan kelemahan politik dan agama telah menciptakan dorongan kuat diadakannya reformasi. Sejak saat itu juga, para pemikir Muslim menghadapi banyak tantangan terhadap gagasan Islam klasik tentang otoritas keagamaan (baca: hadis). Pergolakan di dunia Muslim telah mendorong meluasnya pengujian kembali sumber-sumber klasik hukum Islam karena orang Muslim telah berjuang untuk 
memelihara, menyesuaikan, atau mendefinisikan kembali norma-norma sosial dan hukum dalam menghadapi kondisi yang berubah.

Isu sentral dalam perjuangan yang terus berlangsung ini adalah masalah hakekat, status, dan otoritas Sunnah. Hal ini disebabkan karena status Nabi Muhammad sebagai utusan Allah, perkataan dan perbuatannya diterima oleh sebagian besar Muslim sebagai sebuah sumber hukum kedua setelah Alquran. Dengan demikian, imitatio Mubammadi menjadi dasar bagi hukum Islam.

Selama abad ke-20, kedudukan Sunnah terancam dengan berbagai cara, ketika para pemikir Muslim mencari basis kuat bagi kebangkitan kembali Islam. Masalah Sunnah telah menjadi sisi paling penting dalam krisis Muslim modern seperti krisis otoritas keagamaan, yang menduduki tempat sentral di dalam wacana keagamaan muslim.

Tulisan ini memuat uraian tentang bagaimana sikap para pemikir kontemporer dan metode yang ditawarkannya dalam memahami hadis Nabi. Metode penyajian artikel ini adalah dengan melakukan studi komparatif antara dua persepsi pakar tentang Pemahaman Hadis. Uniknya, pakar yang diteliti bukanlah tergolong sebagai ahli hadis konservatif seperti pengertian pada umumnya. Adapaun ulama kontemporer yang dibahas pada makalah ini adalah metode pemahaman hadis Muhammad al-Ghazali (pendakwah ulung Timur Tengah) dan metode pemahaman hadis Yusuf al-Qardhawi (ahli fikih dan syariat). Tokoh-tokoh ini keduanya diindikasikan mempunyai pengaruh yang cukup mengagumkan di kalangan pengakaji hadis akhir-akhir ini. ${ }^{1}$

1 Secara rinci, Suryadi, dalam ringkasan disertasinya Metode Pemahaman hadis Nabi: Telaab atas Pemikiran Mubammad Al-Ghazali dan Yusuf Al-Qardhawi, yang disampaikan pada Program Pasca Sarjana UIN Sunan Kalijaga Yogyakarta, 2004, h. 4.

\section{METODE PEMAHAMAN} MUHAMMAD AL-GHAZALI

HADIS

Profil Singkat Muhammad Al-Ghazali

Muhammad Al-Ghazali lahir pada

1917 M di al-Bahirah, Mesir. Daerah ini dikenal banyak dilahirkan tokoh-tokoh Islam terkemuka pada zamannya, seperti Muhammad 'Abduh, Mahmud Syaltut, Hasan Al-Bana dan Muhammad al-Madani ${ }^{2}$.

Pada usianya 10 tahun, Muhammad alGhazali sudah hafal Alquran 30 juz. Pendidikan dasar dan menengah, ia tempuh di Sekolah Agama. Pada tahun 1937, ia melanjutkan pendidikannya pada Jurusan Dakwah Fakultas Ushuludddin, Universitas Al-Azhar, Mesir dan lulus pada tahun 1941 M. Setelah itu, al-Ghazali melanjutkan studinya ke Fakultas Bahasa Arab di Universitas yang sama dan selesai pada tahun 1943. Semasa kuliah, ia direkrut oleh Imam Hasan Al-Banna hingga menjadi salah seorang anggota bahkan salah seorang tokoh Ikhwanul Muslimin. Ia aktif melakukan jihad di medan dakwah Islamiyah melalui berbagai forum seminar, pendidikan, pembinaan, khutbah, ceramah dan tulisan.

Muhammad Al-Ghazali lebih dikenal sebagai da'i terutama di Timur Tengah. Materi ceramah yang selalu segar, gaya bahasanya, semangat dan keterbukaannya, merupakan daya tarik dakwah. ${ }^{3}$ Selain sebagai da’i, ia juga seorang akademisi yang disegani baik di almamaternya maupun di berbagai perguruan tinggi lainnya, seperti Universitas Ummul Qura di Makkah, Universitas Qatar di Qatar, Universitas Amir Abdul Qadir al-Islamiyah di Aljazair.

Muhammad Al-Ghazali wafat pada hari sabtu tanggal 9 Syawal $1416 \mathrm{H}$, bertepatan dengan tanggal 6 Maret 1996, ketika ia berada

2. Salman Al-Audah, Fi Hiwar Hadi Ma'a Muhammad Al-Ghazali (t.tp: Rasasah Ammah li Idarah al-Buhus al-Ilmiyah (t.th) h. 5-6

3. M. Quraish Shihab, dalam "Studi Kritis atas Hadis Nabi Mubammad SAW antara Pemahaman Tekstual dan Kontekstual” kata pengantar, (Bandung: Mizan, 1989) 
di Saudi Arabia untuk menghadiri seminar tentang Islam dan Barat. ${ }^{4}$

Sikap Muhammad Al-Ghazali Terhadap Hadis

Pada tahun 1989, syaikh Muhammad al-Ghazali, menerbitkan sebuah buku dengan judul al-Sunnab al-Nabawiyyah Baina Abl al-Fiqh wa Abl al-Hadis. ${ }^{5}$ Buku ini menjadi fokus perhatian dan kontroversi oleh para ulama dimasanya. Dalam bukunya, al-Ghazali mengetengahkan banyak tema pokok tentang otoritas religius, seperti hubungan antara Alquran dan Sunnah, bagaimana posisi hadis Nabi sebagai sumber hukum Islam, dan bagaimana metode kritik hadis. Polemik itu terutama disebabkan oleh hadis-hadis sahih yang dipertanyakan kembali oleh Muhammad al-Ghazali karena dianggap kontradiksi dengan ajaran Alquran, kebenaran ilmiah maupun historis.

Menurut Yusuf Qardhawi, munculnya kritik tajam yang ditujukan kepada Muhammad Al-Ghazali tersebut disebabkan 2 hal, pertama ia tidak mau menggunakan hadis ahad dalam menetapkan akidah. Menurut Muhammad AlGhazali, masalah akidah harus berdasarkan keyakinan bukan dugaan. Hadis-hadis ahad, meskipun sahih tidak memberikan keyakinan dan hanya hadis mutawatir yang mempunyai nilai kepastian. Kedua, penolakan Muhammad Al-Ghazali terhadap beberapa hadis ahad disebabkan bertentangan dengan Alquran, logika ilmu pengetahuan ataupun dengan fakta historis.

Berdasarkan pandangan al-Ghazali di atas, dia menawarkan metode yang diterapkannya untuk memahami sebuah hadis. Secara umum terdapat persamaan antara pemahaman al-Ghazali dengan para Mubaditsun

${ }^{4}$ Bustamin M. Isa H. A. Salim, Metodologi Kririk Hadis, (Jakarta: PT. Raja Grafindo Persada) h. 100

5 Muhammad Al-Ghazali, al-Sunnah alNabawiyyah Bayna Abl al-Fiqh wa Abl al-Hadis (Kairo, 1989, buku ini edisi berbahasa Indonesianya diterbitkan Mizan (1999) berjudul Studi Kritis atas Hadis Nabi Saw.: Antara Pemahaman tekstual dan Kontekstual. sebelumnya dalam menentukan kriteria keshahihan hadis. Namun dalam menentukan keshahihan matan hadis, ia lebih mengedepankan dan terfokus pada kriteria pertama yang ditawarkannya yaitu matan hadis harus sesuai dengan prinsip-prinsip Alquran. Dengan demikian banyak hadis-hadis shahih yang ditolak oleh al-Ghazali, dengan alasan bahwa hadis tersebut bertentangan dengan Alquran dan tidak relevan dengan perkembangan zaman. ${ }^{6}$

\section{Metode Pemahaman Hadis Muhammad Al-Ghazali}

Para ulama sepakat bahwa hadis nabi yang memenuhi kriteria shahib diapandang sebagai bujjah. Untuk itu, ada beberapa kriteria hadis shahih yang disepakati oleh para ulama hadis, yaitu; Kebersambungan sanad hadis (ittishal sanad); Diriwayatkan oleh orang yang adil ('adalab), yaitu mereka harus menjunjung tinggi agama, dan tidak melakukan dosa-dosa besar; Akurasi proses periwayatan (dhabit), seperti periwayat tidak boleh ceroboh atau diketahui memiliki daya ingat yang lemah; Bebas dari syudzudz, yaitu kontradiksi dengan sumber-sumber yang lebih dapat dipercaya; Bebas dari cacat-cacat penyimpangan ('illat qadbihab), yaitu ketidaktepatan dalam melakukan periwayatan. ${ }^{7}$

Lima point di atas adalah syarat diterimanya hadis shahih sebagai bujjah yang merupakan bentuk ringkas dari metode yang digunakan para ulama mutaqaddimun untuk membedakan mana hadis-hadis yang patut dijadikan bujjah dan mana hadis yang tidak. Penerapan sistematis metode ini tampak pada karya-karya ulama-ulama hadis terdahulu, seperti imam Bukhari, imam Muslim, Abu Daud, imam Ahmad Ibn Hanbal dan yang

${ }^{6}$ Contoh hadis-hadis shahih yang ditolak oleh al-Ghazali dapat dilihat dalam karyanya as-Sunnab alNabawiyyah Baina Abli Figh wa Abli Hadis.

7 Para ulama berbeda pendapat tentang interpretasi aturan-aturan ini. Lihat Muhammad 'Ajaj Al-Khathib. Ushul al-Hadis 'Ulumubu wa Musthalabubu, (Beirut: Dar al-Fikr, t.th),. h. 305. 
lainnya. Hal ini merupakan puncak keilmuan hadis klasik.

Namun semua ini berubah pada masa modern, ketika tekanan untuk mereformasi, mereformulasi, dan mengenalkan kembali hukum Islam dan membuat studi hadis relevan kembali di tengah-tengah umat. Para ulama modern yang terkenal dengan tokoh-tokoh pembaharu, seperti Muhammad Abduh, Rasyid Ridha, Abu Zahrah, Imam Ghazali dan lain sebagainya mendorong melakukan gerakan untuk memperkenalkan kembali hukum Islam dalam bentuk tertentu. Hal ini telah memunculkan urgensi praktis untuk mempertanyakan sumber-sumber syari'ah, dan metode untuk menghidupkan kembali syari'ah.

Menurut Muhammad al-Ghazali, ada 5 kriteria untuk menguji kesahihan hadis, 3 berkaitan dengan sanad dan 2 berkaitan dengan matan. Tiga kriteria yang berkaitan dengan sanad adalah;

1. Sebuah hadis harus diriwayatkan oleh seorang yang dikennal sebagal penghafal yang cerdas, teliti, dan memahami apa yang didengarkannya. Pada konteks ini perawi disebut dhabit.

2. Hadis harus diriwayatkan oleh perawi yang mantap kepribadiannya, bertaqwa pada Allah, dan menolak semua pemalsuan yang menyimpang. Pada konteks ini perawi disebut dengan adil.

3. Poin satu dan dua harus dimiliki oleh seluruh perawirawi dalam sanad. ${ }^{8}$

Adapun 2 kriteria lainnya adalah berkaitan dengan matan:

1. Matan hadis tidak syadz, (salah seorang atau beberapa periwayatnya bertentangan periwayatannya dengan periwayat yang lebih akurat dan lebih dapat dipercaya)

2. Matan hadis tidak mengandung illat qadhibah (cacat yang diketahui oleh para

${ }^{8}$ Muhammad Al-Ghazali,op.cit., h. 15 ahli hadis sehingga mereka menolak periwayatannya) ${ }^{9}$

Berdasarkan kriteria kesahihan hadis menurut Muhammad al-Ghazali di atas, maka dapat dinyatakan bahwa beliau berbeda dengan pandangan mayoritas ulama hadis mutaqaddimun. Muhammad al-Ghazali tidak memasukkan ketersambungan sanad sebagai kriteria kesahihan hadis, sementara menurut ulama mutaqaddimun muthlak adanya, bahkan unsur ketiga sebenarnya sudah masuk ke dalam kriteria poin dua. Dalam hal ini Muhammad al-Ghazali tidak memberikan argumentasi sehingga sangat sulit untuk ditelusuri, apakah ini merupakan salah pemikiran atau ada unsur kesengajaan.

Menurut al-Ghazali untuk merealisasikan kriteria-kriteria tersebut, maka diperlukan kerjasama antara mubaddits dengan berbagai ahli-ahli lain termasuk fuqaha', mufassir, ahli ushul fiqh dan ahli ilmu kalam, mengingat materi hadis ada yang berkaitan dengan akidah, ibadah, mu'amalah sehingga memerlukan pengetahuan dengan berbagai ahli tersebut. ${ }^{10}$

Atas dasar pemahaman di atas, alGhazali menawarkan beberapa metode pemahaman hadis atau prinsip-prinsip dasar yang harus dipenuhi ketika hendak berinteraksi dengan Sunnah, supaya dihasilkan pemahaman yang sesuai dengan ajaran agama. Metode ini tidak dinyatakan secara eksplisit oleh alGhazali, akan tetapi hal ini dapat ditemukan dari beberapa contoh hadis yang dikritik dan ditolaknya. Berdasarkan penelitian yang dilakukan oleh Suryadi ${ }^{11}$ terhadap tolok ukur keshahihan sebuah hadis, maka ditemukan

\footnotetext{
9 Ibid.

10 Suryadi, Op.cit., h. 20

11 Hasil penelitian Suryadi dalam rangka mempertahan gelar doktornya dengan judul disertasi: Metode Pemahaman Hadis Nabi: Telaab atas Pemikiran Mubammad Al-Gharali dan Yusuf Al-Qardhawi, yang disampaikan pada Program Pasca Sarjana UIN Sunan Kalijaga Yogyakarta, 2004.
} 
bahwa ada 4 metode pemahaman hadis Nabi oleh imam al-Ghazali;

\section{Matan Hadis Harus Sesuai Dengan Alquran}

Muhammad al-Ghazali mengecam keras orang-orang yang memahami secara tekstual hadis-hadis yang sahih sanadnya, namun matannya bertentangan dengan Alquran. Pemikiran tersebut dilatarbelakangi adanya keyakinan tentang kedudukan hadis sebagai sumber otoritas setelah Alquran. Tidak semua hadis orisinal dan tidak semua dipakai secara benar oleh periwayatnya. Alquran menurut Muhammad al-Ghazali adalah sumber pertama dan utama dari pemikiran dan dakwah, sementara hadis adalah sumber kedua. Dalam memahami Alquran, hadis sangat penting karena penjelas teoritis dan praktis bagi Alquran. Oleh karena itu, sebelum melakukan kajian tentang matan hadis, perlu upaya intensif memahami Alquran sebagaimana pernyataannya, "Telas babwa untuke menetapkan kebenaran suatu hadis dari segi matannya diperlukan ilmu yang mendalam tentang Alquran serta kesimpulan-kesimpulan yang dapat ditarik dari ayat-ayatnya, baik secara langsung atau tidak". ${ }^{12}$

Pengujian dengan ayat Alquran ini mendapat porsi yang lebih oleh al-Ghazali dibanding dengan 3 kriteria lainnya. Bahkan menurut Quraisy Shihab bahwa meskipun Muhammad al-Ghazali menetapkan 4 tolak ukur, namun kaidah nomor 1 yang dianggap paling utama menurut Muhammad alGhazali. ${ }^{13}$

Penerapan kritik hadis dengan pengujian Alquran diarahkan secara konsisten oleh Muhammad al-Ghazali. Oleh karena itu tidak sedikit hadis yang dianggap sahih misalnya terdapat dalam kitab Shabih Bukhari dan Muslim, dianggap dhaif oleh Muhammad al-Ghazali, bahkan secara tegas menyatakan

\footnotetext{
12 Ibid., h. 21

${ }^{13}$ Ibid., h. 29
}

bahwa dalam hal-hal yang berkaitan dengan kemaslahatan dan mu'amalah duniawiyah, akan mengantarkan hadis yang sanadnya dhaif dapat diamalkan, bila kandungan matannya sesuai dengan prinsip-prinsip ajaran Alquran, dari pada hadis yang sanadnya sahih tapi kandungan matannya tidak sesuai dengan inti dari ajaran-ajaran Alquran.

Berkaitan dengan hal di atas. AlGhazali memberi contoh hadis tentang mayat yang disiksa karena tangisan keluarganya.

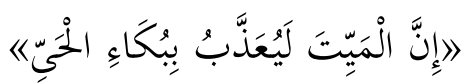

"Sesungguhnya mayat dapat terkena azab karena tangisan keluarganya yang masih hidup"

Hadis di atas terdapat dalam delapan kitab hadis dengan 37 jalur sanad dan telah memenuhi criteria keshahihan sanad, baik dilihat dari ketersambungan sanad, maupun dari segi kapasitas dan kualitas perawi, dan hadis ini juga mempunyai banyak musyahid dan mutabi' sehingga hadis ini semakin baik dan kuat.

Sementara menurut Muhammad AlGhazali dari 37 jalur sanad hadis di atas hanya dua jalur yang dapat diterima, yaitu jalur kelima dan ketujuh yang terdapat dalam Shabih Muslim. Pemikiran Muhammad Al-Ghazali ini didasarkan pada pendapat 'Aisyah mengkritik sahabat yang meriwayatkan hadis di atas. Alasan penolakannya adalah dianggap bertentangan dengan Alquran. Menurut 'Aisyah riwayat mereka bertentangan dengan pesan Alquran yang artinya: Tidaklah seseorang menanggung dosa orang lain. ${ }^{14}$

Demikianlah imam al-Ghazali mengkritisi hadis di atas yang berlandaskan kepada pendapat 'Aisyah yang menolak dengan tegas periwayatan suatu hadis yang bertentangan dengan Alquran. Meskipun begitu, hadis tersebut masih saja tercantum dalam kitab-kitab hadis sahih. Bahkan Ibnu Sa'ad dalam Tabaqat al-Kabirnya menyebutkan

${ }^{14}$ Q.S. Al-An'am: 164. 
berulang-ulang dengan redaksi yang berbedabeda. Sebagian ulama memberikan interpretasi bahwa yang dimaksud dengan hadis tersebut adalah orang Islam tersebut merasa sakit setelah kematiannya disebabkan tangisan keluarganya.

\section{Matan Hadis Harus Sesuai dengan Hadis Shabih Lainnya}

Pengujian ini memiliki pengertian bahwa matan hadis yang dijadikan dasar argumen tidak bertentangan dengan hadis mutawatir dan hadis lainnya yang lebih sahih. Menurut Muhammad al-Ghazali hukum yang berdasarkan agama tidak boleh diambil hanya dari sebuah hadis yang terpisah dengan hadis yang lainnya, tetapi setiap hadis harus dikaitkan dengan hadis lainnya, kemudian hadis-hadis yang tersambung itu dikomparasikan dengan apa yang ditunjukkan oleh Alquran. Sebagai contoh hadis tentang larangan bagi wanita shalat jama'ah di masjid.

Shalat jamaah adalah salah satu syi'ar Islam, sehingga sebagian ulama berpendapat bahwa ia adalah fardhu 'ayn pada kelima waktu shalat, tidak boleh meninggalkannya dengan alasan yang tidak dibenarkan. Akan tetapi mayoritas fuqahâ' menetapkannya sebagai Sunnah muakkadah (yang sangat dianjurkan). Namun ditemukan dalam riwayat hadis tentang larangan perempuan shalat jama'ah di masjid :

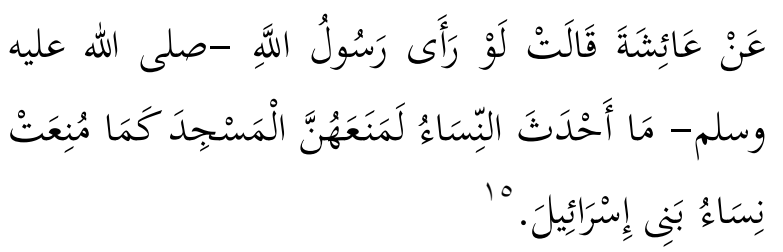

Dari Aisyar RA, Jika Nabi SAW melibat apa yang terjadi/dilakukan perempuan, niscaya Nabi akan melarang mereka ke Masjid seperti terlarangnya wanita Bani Israil (dulu).

15 Abu 'Abdullah Ahmad ibn Hanbal ibn Hilal ibn Asad Al-Syaibani (selanjutnya disebut Ahmad Ibn Hanbal), Musnad Ahmad, hadis saidah 'Aisyah, hadis no 26735
Selain itu ada pula hadis yang menganjurkan wanita apabila melaksanakan shalat di rumahnya, agar ia memilih tempat yang paling sepi dan paling terpisah. Dengan demikian sehingga shalatnya di terowongan rumah lebih afdhal daripada shalatnya di kamar. Dan shalatnya di dalam kegelapan lebih afdhal daripada tempat yang terang.

Menurut Muhammad aL-Ghazali, perawi hadis ini secara terang-terangan melempar jauh-jauh semua Sunnab Nabi SAW sang pembawa risalah, yang sampai kepada kita secara mutawatir. ${ }^{16}$

Hadis di atas tentang larangan perempuan shalat di masjid ditolak oleh AlGhazali, karena dianggap bertentangan dengan amalan Rasulullah yang membiarkan perempuan mengikuti shalat jamaah di masjid dengan menyediakan pintu khusus bagi perempuan yang masuk masjid untuk mengikuti shalat jamah. Rasul juga pernah memendekkan shalat Subuh dengan membaca surat-surat pendek ketika mendengar tangis bayi, karena dikhawatirkan sang ibu tidak khusyu' karena tangisan anaknya. ${ }^{17}$

Al-Ghazali berpendapat, bahwa keikut sertaannya dalam jemaah seperti itu, hanya dianjurkan baginya setelah ia menyelesaikan semua tugas-tugasnya di rumah. Jika ia telah melakukannya, maka suaminya tidak berhak melarangnya pergi ke mesjid. Tentang hal ini, ada sebuah hadis yang berbunyi:

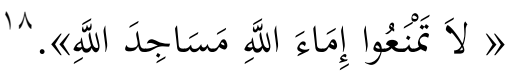

Janganlah kamu menghalangi hamba-hamba Allah dari mengunjungi mesjid-mesjid Allah.

Menurut al-Ghazali, bahkan Nabi tidak memberikan sugesti agar perempuan lebih baik shalat di rumah. Dengan demikian, hadis yang

${ }^{16}$ Muhammad al-Ghazali, op.cit, h. 71

${ }^{17}$ Ibid., h. 70-73

18 Sulaiman ibn al-Asy'ats ibn Syida ibn Umar al-Azadi Abu Daut, Al-Sijistani, Sunan Abi Daud, bab Mâ jâ-a fì Khuruj al-Nisa' Ila Masjid, juz 2, hadis no 566, h. 265 
menjelaskan tentang larangan perempuan ikut shalat di masjid adalah bathil. Hadis ini juga tidak dijumpai dalam kitab sahih Bukhari dan Muslim.

\section{Matan Hadis Sesuai dengan Fakta Historis}

Suatu hal yang tidak bisa dipungkiri, bahwa hadis muncul dan berkembang dalam keadaan tertentu, yaitu pada masa Nabi Muhammad hidup, oleh karena itu hadis dan sejarah memiliki hubungan sinergis yang saling menguatkan satu sama lain. Adanya kecocokan antara hadis dengan fakta sejarah akan menjadikan hadis memiliki sandaran validitas yang kokoh. Demikian pula sebaliknya, bila terjadi penyimpangan antara hadis dan sejarah, maka salah satu diantara keduanya diragukan kebenarannya.

Sebagai contohnya dalah hadis tentang perempuan menjadi pemimpin:

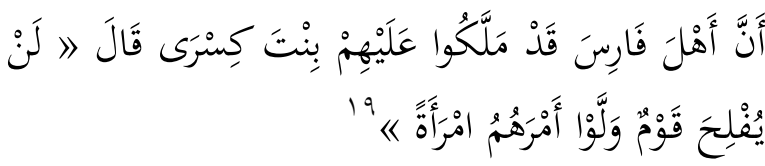

"Kerajaan Persia diperintah oleb Putri Kaisar, kemudian Nabi menimpali "Tidak akan beruntung suatu kaum jika dipimpin oleh seorang wanita”,".

Jumhur ulama memahami hadis tersebut secara tekstual. Mereka berpendapat bahwa berdasarkan petunjuk hadis tersebut, pengangkatan perempuan menjadi kepala Negara, hakim pengadilan dan berbagai jabatan yang setara denganny dilarang. Mereka menyatakan bahwa perempuan menurut syari'at hanya diberi tanggung jawab untuk menjaga harta suaminya. ${ }^{20}$

Hadis tersebut seharusnya difahami secara kontekstual, yaitu dengan mengetahui latar belakang keluarnya hadis tersebut, antara lain dengan memahami kondisi dan budaya

${ }^{19}$ Muhammad ibn Ismail ibn Ibrahim ibn alMughirah al-Bukhari, Shabih al-Bukhari, dalam Kitab AlNabi, hadis no 4425

${ }^{20}$ Ibn Hajar Al-'Asqalani, Fath al-Bari, juz VIII, h. 128 masyarakat Persia dan system politik yang dianut ketika itu, sehingga hadis tersebut dapat diterapkan pada situasi yang diinginkan Nabi Muhammad saw. dan ditinggalkan pada akondisi yang berbeda.

Menurut Muhammad al-Ghazali, ketika Nabi Muhammad saw. mengucapkan hadis tersebut bangsa Persia dipaksa mundur dan luas wilayahnya semakin menyempit. Sebenarnya masih ada kemungkinan untuk menyerahkan kepemimpinan Negara kepada seorang Jendral yang piawai, yang mungkin dapat menghentikan kekalahan demi kekalahan. Namun paganism politik telah menjadikan rakyat dan Negara sebagai harta warisan yang diberikan kepada perempuan muda yang tidak tahu apa-apa. Hal itulah yang menandakan bahwa negeri Persia sedang menuju kehancuran total. ${ }^{21}$

Pernyataan Muhammad Al-Ghazali di atas memberi isyarat bahwa perempuan yang tidak boleh diserahi tugas sebagai pemimpin oleh Nabi Muhammad saw. adalah perempuan yang tidak memenuhi syarat kepemimpinan. Jadi, hadis di atas tidak dapat dijadikan dasar penolakan dan penerimaan perempuan sebagai pemimpin.

\section{Matan Hadis Harus Sesuai dengan Kebenaran Ilmiah}

Pengujian ini dapat diartikan bahwa setiap kandungan matan hadis tidak boleh bertentangan dengan teori ilmu pengetahuan atau penemuan ilmiah, memenuhi rasa keadilan atau tidak bertentangan dengan hak asasi manusia. Oleh karena itu, adalah tidak masuk akal jika hadis nabi mengabaikan rasa keadilan. Menurut Al-Ghazali, bagaimanapun sahihnya sanad sebuah hadis, jika matan informasinya bertentangan dengan prinsipprinsip hak asasi manusia, maka hadis tersebut tidak layak dipakai.

${ }^{21}$ Muhammad al-Ghazali, op.cit. h. 64-65 
Contoh hadis tentang tidak adanya qishas bagi seorang muslim yang membunuh

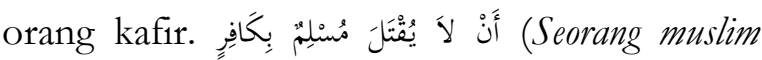
tidak boleh di bunub karena membunuh orang keafir). ${ }^{22}$

Al-Ghazali menolak hadis tersebut disebabkan mengabaikan rasa keadilan dan tidak menghargai jiwa kemanusiaan. Karena antara muslim dan kafir sebenarnya mempunyai hak dan kewajiban yang sama.

Jika dicermati, indikator yang ditanamkan oleh Al-Ghazali dalam kritik matan bukanlah sesuatu yang baru. Al-Ghazali sendiri mengakui, bahwa apa yang dilakukannya sudah dilakukan oleh ulama terdahulu. Yang paling penting dari semua itu adalah bagaimana mempraktikkan indikator kritik matan tersebut dalam berbagai matan hadis Nabi.

\section{METODE PEMAHAMAN YUSUF AL-QARDHAWI}

Profil Singkat Yusuf al-Qardhawi

Nama lengkapnya adalah Yusuf AlQardhawi. Beliau dilahrkan di desa Saft Turab di tengah Delta sungai Nil, daerah Mahallah Kubra, Republik Arab Mesir, pada tanggal 9 September 1926. Pada sepuh tahun, ia telah berhasil menghafalkan Alquran dengan bacaan yang baik. Dengan keahliannya itu, ia dijadikan imam shalat lima waktu di desanya pada usia yang sangat muda.

Pendidikan formalnya ditempuh di alAzhar Mesir, kecuali tingkat Aliyah, ia tempuh di Ma'had al-Bubuts wa al-Dirasah al-Arabiyah al'Aliyah, sehingga mendapatkan ijazah diploma tinggi dalam bidang bahasa dan sastra Arab. Namun keahliaanya yang menonjol adalah dalam bidang keushuluddinan. Hal ini didukung oleh pelajarannya di fakultas

22 Imam al-Bukhari, op.cit. dalam Kitab alDiyat, Bab La Yaqtul al-Muslim bi al-Kafir, hadis no. 6915
Ushuluddin yang diselesaikannya pada tahun $1960 .{ }^{23}$

Sikap Yusuf Al-Qardhawi Terhadap Hadis

Di antara para pemikir kontemporer, al-Qardhawi memberikan penjelasan yang luas tentang bagaimana pemikirannya tentang hadis yang dikembangkan menjadi metode sistematis untuk menilai otentisitas hadis. Menurut alQardhawi, posisisi Sunnah Nabi dalam Islam memiliki lima karekteristik, yaitu komprehensif (manhaj syumul), seimbang (manhaj mutawarzun), melengkapi (manhaj takamuly), historis (manhaj waqi'iy),dan memudahkan (manhaj muyassar). Ketiga karakteristik ini akan mendatangkan pemahaman yang utuh terhadap suatu hadis. ${ }^{24}$

Atas dasar inilah maka Al-Qardhawi menetapkan tiga hal juga yang harus dihindari dalam berinteraksi dengan Sunnah, yaitu pertama, penyimpangan kaum ekstrim, kedua, manipulasi orang-orang sesat, (Intibal abl bathil), yaitu pemalsuan terhadap ajaran-ajaran Islam, dengan membuat berbagai macam bid'ah yang jelas bertentangan dengan aqidah dan syari'ah, dan ketiga, penafsiran orang-orang bodoh (ta'wil al-jabilin). Oleh sebab itu, pemahaman yang tepat terhadap Sunnab adalah mengambil sikap moderat (wasathiya), yaitu tidak berlebihan atau ekstrim, tidak menjadi kelompok sesat, dan tidak menjadi kelompok yang bodoh. ${ }^{25}$

Metode Pemahaman Hadis Yusuf al-Qardhawi Untuk merealisasikan metodenya, Yusuf al-Qardhawi menerapkan prinsipprinsip dasar yang harus ditempuhnya ketika berinteraksi dengan Sunnah, yaitu;

1. Meneliti kesahihan hadis sesuai dengan acuan umum yang ditetapkan oleh pakar

${ }^{23}$ Bustamin, dkk. op.cit., h. 89-90

${ }^{24}$ Yusuf al-Qardhawi, Kaifa Nata'amal Ma'a alSunnah al-Nabawiyyah, (Mesir: Dar al-Syuruq, 2002), h. 25-34

${ }^{25}$ Ibid., h. 35-41 
hadis yang dapat di percaya, baik sanad maupun matan.

2. Memahami Sunnab sesuai dengan pengetahuan bahasa, konteks, asbab alwurud teks hadis untuk menentukan makna suatu hadis yang sebenarnya.

3. Memastikan bahwa Sunnab yang dikaji tidak bertentangan dengan nash-nash yang lebih kuat. ${ }^{26}$

Adapun untuk melakukan prinsipprinsip dasar itu, maka al-Qardhawi mengemukakan 8 langkah ${ }^{27}$,yaitu;

Memahami Hadis Sesuai dengan Petunjuk Alquran.

Menurut Al-Qardhawi, untuk memahami suatu hadis dengan benar harus sesuai dengan petunjuk Alquran. Karena terdapat hubungan yang signifikan antara hadis dengan Alquran. Oleh karena itu tidak mungkin kandungan suatu hadis bertentangan dengan ayat-ayat Alquran yang muhkam, yang berisi keterangan-keterangan yang jelas dan pasti.

Pertentangan tersebut bisa saja terjadi karena hadis tersebut tidak sahih, atau pemahamannya yang kurang tepat, atau yang dianggap bertentangan itu bersifat semu dan bukan hakiki. Dengan demikian, menurut $\mathrm{Al}$ Qardhawi, setiap muslim diharuskan untuk mentawaqqufkan hadis yang terkesan bertentangan dengan ayat-ayat muhkam, selama tidak ada penafsiran (ta'wil) yang dapat diterima.

Dalam hal ini, Al-Qardhawi mengemukakan contoh hadis tentang nisab tanaman yang wajib dikeluarkan zakatnya. Yang dijadikan dasar para ulama fikih untuk membatasi jenis atau macam tanaman tertentu (bukan berbentuk sayuran) yang wajib dikeluarkan zakatnya. Di samping itu, AlQardhawi tidak menyetujui pemahaman yang

\footnotetext{
${ }^{26}$ Ibid., 43-45

${ }^{27}$ Ibid., h. 113-200
}

menganggap bahwa tidak diwajibkannya zakat atas sayuran karena cepat rusak sehingga tidak dapat di simpan di bait al-mal terlalu lama

\section{Menghimpun Hadis-Hadis yang Setema.}

Menurut Al-Qardhawi, untuk menghindari kesalahan dalam memahami kandungan hadis yang sebenarnya perlu menghadirkan hadis-hadis lain yang setema. Adapun prosedurnya ialah dengan menghimpun hadis sahih yang setema kemudian mengembalikan kandungan hadis yang mutasyabih kepada yang mubkam, mengantarkan yang mutlaq kepada yang muqayyad, yang 'am ditafsirkan dengan yang khas. Hal ini dikarenakan posisi hadis untuk menafsirkan Alquran, dan menjelaskan maknanya, maka sudah pasti bahwa ketentuanketentuan tersebut harus berlaku bagi hadis secara keseluruhan.

Dalam hal ini, Al-Qardhawi menguraikan contoh sebuah hadis tentang hukum pertanian. Pertama-tama beliau mengemukakan hadis yang mencela orang yang membawa alat pertanian masuk rumah. Dari abu 'Umamah al-Bahili ketika melihat alat untuk membajak, ia berkata; saya mendengar Nabi saw bersabda; ${ }^{28}$

$$
\text { لا يدخل قوم هذا بيت الا أدخله الله الذل }
$$

('Tidak akan masuk (alat) ini ke dalam rumah suatu kaum, kecuali Allah pasti memasukekan kehinaan ke dalamnya)

Setelah itu, ia mengemukakan pula hadis-hadis yang menunjukkan keutamaan bercocok tanam, di antaranya;

$$
\begin{aligned}
& \text { ما من مسلم يغرس غرسا او يزرعزرعا فيأكل منه طير } \\
& \text { او إنسان أو بهيمة إلاّ كان له به صدقة }
\end{aligned}
$$

28 Riwayat Bukhari bab al-Muzara'ah. Lihat Ibnu Hajar al-'Asqalani, Bulugh al-Maram, (Surabaya: alHidayah, t.th), h. 194 
(Tidak seorang Muslim menanam tanaman, lalu buabnya dimakan burung atau manusia atau binatang, kecuali ia pasti beroleh sedekah. $)^{29}$

Berdasarkan dua hadis yang secara lahiriah tampak bertentangan tersebut, Yusuf al-Qardhawi mencoba mengoleksi semua hadis yang berkaitan antara satu dengan yang lainnya. Kemudian mengemukakan pemahaman yang tepat dalam memahaminya, baik dengan cara mengkompromikan atau mentakwilkan hadis yang secara lahiriah tampak menyalahi hadis-hadis yang lain.

Kompromi atau Tarjih terhadap Hadis-Hadis yang Kontradiktif.

Dalam pandangan Al-Qardhawi, pada dasarnya nash-nash syari'at tidak akan saling bertentangan. Pertentangan yang mungkin terjadi adalah bentuk lahiriyahnya bukan dalam kenyataan yang hakiki. Adapun solusi yang ditawarkan Al-Qardhawi adalah, al-jam'u (penggabungan atau pengkompromian). Bagi Al-Qardhawi, hadis yang tampak bertentangan dengan hadis yang lain dapat dilakukan dengan cara mengompromikan hadis tersebut.

Dalam hal ini, Al-Qardhawi memberikan sebuah contoh hadis tentang larangan ziarah kubur bagi perempuan. "Dari abu Hurairah, bahwa Rasulullah saw melaknat kaum perempuan yang sering menziarahi kuburan." Hadis ini sahih. Diriwayatkan juga dari Ibnu 'Abbas dan Hasan ibn Sabit dengan lafaz "nabi melaknat para perempuan peziarah kuburan".

Walaupun demikian, ada hadis-hadis lainnya yang isinya berlawanan dengan hadis hadis-hadis di atas. Yakni yang dapat dipahami darinya, bahwa kaum perempuan diizinkan menziarahi kuburan, sama seperti laki-laki. Diantara riwayatnya adalah

29 Riwayat Bukhari dan Muslim dari Anas. Lihat Ibnu Hajar al-'Asqalani, Ibid., h. 195

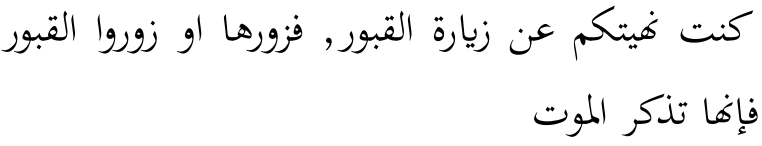

(Aku pernah melarang kalian menziarabi kuburan, kini ziarablab" atau "ziarabilah kuburan-kuburan, sebab itu akan mengingatkean kepada maut). ${ }^{30}$

\section{Memahami Hadis Sesuai dengan Latar Belakang,} Situasi dan Kondisi serta Tujuannya.

Menurut Al-Qardhawi, dalam memahami hadis nabi, dapat memperhatikan sebab-sebab atau latar belakang diucapkannya suatu hadis atau terkait dengan suatu illat tertentu yang dinyatakan dalam hadis, atau dipahami dari kejadian yang menyertainya. Hal demikian mengingat hadis nabi dapat menyelesaikan problem yang bersifat lokal, partikular, dan temporer. Dengan mengetahui hal tersebut seseorang dapat melakukan pemahaman atas apa yang bersifat khusus dan yang umum, yang sementara dan abadi. Dengan demikian, menurut Al-Qardhawi, apabila kondisi telah berubah dan tidak ada illat lagi, maka hukum yang berkenaan dengan suatu nas akan gugur dengan sendirinya. Hal itu sesuai dengan kaidah hukum berjalan sesuai dengan illatnya, baik dalam hal ada maupun tidak adanya. Maka yang harus dipegang adalah maksud yang dikandung dan bukan pengertian harfiyahnya.

Membedakan antara Sarana yang Berubah-ubab dan Tujuan yang Tetap.

Menurut Al-Qardhawi, memahami hadis nabi harus memperhatikan makna substansial atau tujuan, sasaran hakekat teks hadis tersebut, sarana yang tampak pada lahirnya hadis dapat berubah-ubah. Untuk itu tidak boleh mencampuradukkan antara tujuan hakiki yang hendak dicapai hadis dengan sarana temporer atau lokal. Dengan demikian, bila suatu hadis menyebutkan sarana tertentu

30 Jalal al-Din Al-Suyuthi, al-Jami' al-Shaghir fi Ahadis al-Basyir wa al-Nadzir, (Surabaya: al-Hidayah, t.th.), h. 458 
untuk mencapai tujuan, maka sarana tersebut tidak bersifat mengikat, karena sarana tersebut ada kalanya berubah karena adanya perkembangan zaman, adat dan kebiasaan.

\section{Membedakan antara yang Hakekat dan Ungkapan}

Teks-teks hadis banyak sekali yang menggunakan majas atau metafora, karena rasulullah adalah orang Arab yang menguasai balaghah. Rasul menggunakan majas untuk mengemukakan maksud beliau dengan cara yang sangat mengesankan. Adapun yang termasuk majas adalah; majas lughawi, aqli, isti'arah. Misalnya hadis tentang sifat-sifat Allah. Hadis semacam ini tidak bisa secara langsung dipahami, tapi harus perhatikan berbagai indikasi yang menyertainya, baik yang bersifat tekstual ataupun kontekstual.

\section{Membedakan antara yang Gaib dan yang Nyata.}

Dalam kandungan hadis ada hal-hal yang berkaitan dengan alam gaib, misalnya hadis yang menyebutkan tentang makhlukmahluk yang tak dapat dilihat seperti malaikat, jin, syetan, iblis, 'ars, kursy, qalam dan sebagainya. Terhadap hadis-hadis tentang alam gaib, Al-Qardhawi sesuai dengan Ibnu Taimiyah, yaitu menghindari ta'wil serta mengembalikan itu kepada Allah tanpa memaksakan diri untuk mengetahuinya.

Memastikan Makna Kata-kata dalam Hadis

Untuk dapat memahami hadis dengan sebaik-baiknya, menurut Al-Qardhawi penting sekali untuk memastikan makna dan konotasi kata-kata yang digunakan dalam susunan hadis, sebab konotasi kata-kata tertentu adakalanya berubah dalam suatu masyarakat ke masyarakat lainnya.

Implementasi Pemahaman Muhammad Al-Ghazali Dan Yusuf Al-Qardhawi

Dari pemikiran yang ditawarkan kedua tokoh tersebut mengindikasikan bahwa metode yang yang ditawarkan oleh
Al-Ghazali dan al-Qardhawi telah menimbulkan dialog yang marak baik yang pro maupun yang kontra, yang pada akhirnya membuka peluang adanya upaya pengembangan dalam wawasan studi pemikiran hadis.

Secara spesifik gagasan pemikiran mereka bukan sesuatu yang sama sekali baru. Beberapa kriteria yang ditawarkan keduanya merupakan refleksi hasil dialog dan pembacaan yang dilakukan keduanya dari realitas masyarakat dan berbagai konsep yang ditawarkan para ulama jauh hari sebelumnya. Selain itu, pentingnya memberikan corak baru dalam studi pemahaman hadis, mengingat jarak waktu yang memisahkan realitas sekarang ini dengan sejarah bagaimana sebuah hadis muncul.

Jika dicermati beberapa prinsip pemahaman hadis nabi yang ditawarkan oleh Muhammad Al-Ghazali dan Yusuf AlQardhawi sebenarnya sangat urgen untuk menggali nilai-nilai hadis yang relevan dengan kebutuhan historis sekarang ini. Hal ini penting mengingat pemahaman atas kedudukan hadis nabi harus relevan dengan dirinya dan pada saat yang sama menjadi relevan dengan masyarakat sekarang ini. Relevan dengan dirinya sendiri berarti kandungan maknanya terbatas pada nilai-nilai yang dikandungnya, relevan dengan kondisi masyarakat sekarang ini berarti bahwa relevansi tersebut berlangsung pada pemahaman yang rasional. $^{31}$

Dengan model yang ditawarkan oleh kedua tokoh tersebut, banyak menjawab berbagai problem realitas sosial umat Islam saat ini. Dengan kata lain, kedua tokoh tersebut mempertegas bahwa Islam adalah agama yang universal yang berlaku untuk setiap masa dan tempat, maka secara substansial formulasi tersebut mengisyaratkan

31 Daniel W. Brown, Menyoal Relevansi Sunnah Dalam Islam Modern (Bandung: Mizan, 1996), h. 18-19 
fleksibilitas ajaran Islam, bukan sebaliknya sebagai sesuatu yang kaku dan ketat.

Bagaimanapun juga berbagai macam temuan dan teknologi yang cukup pesat mengharuskan perlunya pengkajian terhadap pemahaman hadis Nabi. Interaksi antara budaya yang berkembang dengan ajaran Islam yang bersumber dari teks, untuk selanjutnya dapat dipastikan akan berhadapan dengan kenyataan yang lebih berat dan kompleks. Oleh sebab itu, aspek budaya tidak dapat diabaikan dalam kajian hadis. ${ }^{32}$

Munculnya pemahaman hadis perspektif Yusuf Qardhawi dan Muhammad Al-Ghazali mengarah pada upaya pengembangan pemikiran hadis sebagai sesuatu yang positif untuk ditumbuhkembangkan. Beberapa kriteria yang ditawarkan Yusuf Qardhawi dan Muhammad Al-Ghazali telah memberi manfaat dalam menggali nilai-nilai hadis yang relevan konteks historis saat ini. ${ }^{33}$ Namun disisi lain harus disadari, maraknya berbagai pemahaman terhadap hadis nabi membuka peluang semakin melebarnya perpecahan di kalangan umat Islam, jika perbedaan pandangan itu tidak disikapi secara bijak, dengan menganggap produk mereka sendiri yang paling benar dan pemikiran orang/kelompok lain yang berseberangan dengan mereka adalah salah.

\section{KESIMPULAN}

Pemahaman kontekstual terhadap hadis pada saat sekarang dan untuk yang akan datang memang suatu keniscayaan. Harus diakui, tawaran metode pemahaman hadis dan implementasinya yang dikemukakan Muhammad Al-Ghazali dan Yusuf Qardhawi dan telah memberi kontribusi yang cukup besar dalam menjawab berbagai persoalan

${ }^{32}$ Ibid., h. 35

33 Suryadi, Pendekatan Tematik Dalam Memahami Hadis, dalam Jurnal Esensia Vol 3 No. 1, Januari, h. 50 umat Islam saat ini, terlebih keduanya concern terhadap metode dan contens (isi)-nya sekaligus.

Adapun metode pemahaman hadis Muhammad al-Ghazali harus diukur dari empat criteria keshahihan matan hadis, yaitu: Matan hadis harus sesuai dengan Alquran; Matan hadis harus sesuai hadis shahih lainnya; Matan hadis harus sesuai dengan fakta sejarah; Matan hadis harus sesuai dengan kebenaran ilmiah.

Sementara Yusuf al-Qardhawi lebih luas dari empat hal yang dikemukakan Muhammad al-Ghazali. Adapun langkahlangkah dalam memahami menurut alQardhawi adalah; Memahami hadis sesuai dengan petunjuk Alquran; Menghimpun hadishadis yang setema; Kompromi atau tarjih bagi hadis yang tampak kontradiktif; Memahami hadis sesuai dengan latar belakang, situasi, kondisi dan tujuannya; Membedakan antara sarana yang berubah-berubah dan tujuan yang tetap; Membedakan antara hakekat dan ungkapan; Membedakan yang ghaib dan yang nyata; dan Memastikan makna kata dalam hadis.

Kedua pakar tersebut sejatinya berusaha untuk mengimplementasikan pemahaman hadis berdasarkan zaman dan kondisi sosial yang berlaku saat ini. Meskipun keduanya tidak tergolong ahli hadis yang banyak menghafal hadis, setidaknya keduanya telah memberikan warna dalam perkembangan pemahaman hadis agar dapat selalu terintegrasi dengan waktu dan kondisi. 


\section{DAFTAR KEPUSTAKAAN}

Al-Audah , Salman, Fi Hiwar Hadi Ma'a Mubammad Al-Ghazali t.tp: Rasasah Ammah li Idarah alBuhus al-Ilmiyah t.th

Brown, W, Menyoal Relevansi Sunnah Dalam Islam Modern, Bandung: Mizan, 1996

Al-Ghazali, Muhammad, Al-Sunnah al-Nabawiyyah Bayna Abl Al-Fiqh wa Abl Al-Hadis (Kairo, 1989, buku ini edisi berbahasa Indonesianya diterbitkan Mizan (1999) berjudul Studi Kritis atas Hadis Nabi Saw.: Antara Pemahaman tekstual dan Kontekstual.

Al-Khathib, Muhammad ‘Ajaj. Ushul al-badis 'Ulumubu wa Musthalahubu, Beirut: Dar al-Fikr, t.th

Abu 'Abdullah Ahmad ibn Hanbal ibn Hilal ibn Asad Al-Syaibani, Musnad Abmad, tth

Bustamin M. Isa H. A. Salim, Metodologi Kririk Hadis, Jakarta: PT. Raja Grafindo Persada, 2004

Sulaiman ibn al-Asy'ats ibn Syida ibn Umar al-Azadi Abu Daud, al-Sijistani, Sunan Abi Daud, tth

Muhammad ibn Ismail ibn Ibrahim ibn al-Mughirah al-Bukhari, Shahih al-Bukhari, tth

Al-Qardhawi, Yusuf, Kaifa Nata'amal Ma'a al-Sunnah al-Nabawiyyah, Mesir: Dar al-Syuruq, 2002

Suryadi, Metode Pemahaman Hadis Nabi (Telaah Atas Pemikiran Muhammad Al-Ghazali Dan Yusuf AlQardhawi). Ringkasan Disertasi, Yogyakarta: Program Pasca sarjana UIN Sunan Kalijaga, 2004

Al-Suyuthi, Jalal al-Din, al-Jami' al-Shaghir fi Ahadis al-Basyir wa al-Nadzir, Surabaya: al-Hidayah, t.th. 